Article

\title{
Structural, Non-Covalent Interaction, and Natural Bond Orbital Studies on Bromido-Tricarbonyl Rhenium(I) Complexes Bearing Alkyl-Substituted 1,4-Diazabutadiene (DAB) Ligands
}

\author{
Reza Kia * and Azadeh Kalaghchi \\ Chemistry Department, Sharif University of Technology, Tehran P.O. Box 11155-3516, Iran; \\ azade_ka8757@yahoo.com \\ * Correspondence: rkia@sharif.edu or zsrkk@yahoo.com; Tel.: +98-21-66165332; Fax: +98-21-66029165
}

Received: 28 February 2020; Accepted: 31 March 2020; Published: 1 April 2020

\begin{abstract}
The synthesis, characterization, structural and computational studies of $\operatorname{Re}(\mathrm{I})$ tricarbonyl bromo complexes bearing alkyl-substituted 1,4-diazabutadiene ligands, $\left[\operatorname{Re}(\mathrm{CO})_{3}(1,4-\mathrm{DAB}) \mathrm{Br}\right]$, where $1,4-\mathrm{DAB}=\mathrm{N}, \mathrm{N}$-bis(2,4-dimethylbenzene)-1,4-diazabutadiene,

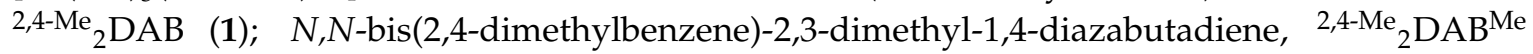
(2); N,N-bis(2,4,6-trimethylbenzene)-1,4-diazabutadiene, $2,4,6-\mathrm{Me}_{3} \mathrm{DAB}$ (3); and $N, N$-bis(2,6diisopropylbenzene)-1,4-diazabutadiene, ${ }^{2,6-\mathrm{ipr}}{ }_{2} \mathrm{DAB}$ (4) are reported. The complexes were characterized by different spectroscopic methods such as FT-IR, ${ }^{1} \mathrm{H}-\mathrm{NMR},{ }^{13} \mathrm{C}-\mathrm{NMR}$, and elemental analyses and their solid-state structures were confirmed by X-ray diffraction. In each complex, the Re(I) centre shows a distorted octahedral shape with a facial geometry of carbonyl groups. The gas phase geometry of the complexes was identified by density functional theory. Interesting intermolecular $\mathrm{n} \cdots \pi^{*}$ interactions of complexes $\mathbf{1}$ and $\mathbf{3}$ were investigated by non-covalent interaction index (NCI), and natural bond orbital (NBO) analyses. The intramolecular $\mathrm{n} \cdots \sigma^{*}, \sigma^{\cdots} \pi^{*}, \pi \cdots \sigma^{*}$ interactions were also studied in complexes 3 and 4.
\end{abstract}

Keywords: Rhenium(I) tricarbonyl; Diazabutadiene; NBO; Non-covalent interactions

\section{Introduction}

Transition metal carbonyl complexes have become one of the most important classes of coordination compounds in inorganic chemistry. These complexes are not only a subject of interest for basic synthesis and study in academic research but are also very important as homo- and heterogeneous catalysts in industry. The chemical bonding in transition metal carbonyl complexes themselves, or in metal carbonyl bearing diimine ligands, is based on the classical concept of synergistic $\sigma$-donation and $\pi$-back donation between the ligand (carbonyl or diimine) and the metal, introduced by Dewar-Chatt-Duncanson in 1951. An understanding of such properties of transition metal carbonyl complexes helps produce required knowledge of the properties of the molecular orbitals, spectra, and appropriate excited states [1]. Among different metal carbonyl complexes, $\operatorname{Re}(\mathrm{I})$-tricarbonyl complexes with diimine ligands of the type $\left[\operatorname{Re}(\mathrm{CO})_{3}(\alpha \text {-diimine })(\mathrm{X})\right]^{0 /+}$, in which $\mathrm{X}$ is a halide, bridging ligand, organic donor/acceptor, nitrogen donor or some other monodentate or ambidentate ligands, have been the subject of much attention, mainly because of their photophysical and photochemical properties [2-4] and their use in the photoreduction and electroreduction of $\mathrm{CO}_{2}$ to $\mathrm{CO}[5,6]$, a key process in the conversion and storage of solar energy as a model in natural photosynthesis, and in supramolecular chemistry and catalysis [7-10]. The photo-behaviour of these complexes may be interpreted in terms of three types of excited states: metal-to-ligand charge transfer (MLCT) states, ligand-to-ligand charge transfer (LLCT) 
states, and intra-ligand (IL) states [11-16]. On the other hand, the spectroscopic properties of the $\operatorname{Re}(\mathrm{I})$-tricarbonyl complexes are ligand-dependent and can be tuned by changing the chelated diimine and/or axial ligands. As such, the quantitative description of the electronic properties of diimine ligands based on their $\sigma$-donation and $\pi$-back donation nature can clarify such properties. By changing the electronic and steric effects in the DAB ligands in their $\mathrm{Ni}(\mathrm{II})$ and $\mathrm{Pd}(\mathrm{II})$ complexes, they can be utilized as efficient catalysts in alkene polymerization $[17,18]$. The tuning of such electronic and steric effects has been examined before in some iminophenol complexes $[19,20]$. Besides all the aforementioned properties, one of the interesting features of metal carbonyl complexes is the presence of intra- and/or intermolecular $\mathrm{n} \cdots \pi^{*}$ interactions, which were not the subject of much attention experimentally and theoretically until their importance was noticed by Echeverría [21]. Since its introduction by Burgi-Dunitz, the so-called Burgi-Dunitz trajectory in the geometrical reaction coordinates in the nucleophilic addition to carbonyl group, most of the studies were focused on organic and biological systems [22-32].

It has been demonstrated that $\mathrm{M}-\mathrm{CO}$ (lone pair) $\cdots \pi$ interactions are relevant in the structures of a number of transition metal carbonyl complexes, and they have important effects on their internal geometry in the related complexes and supramolecular interactions of metal carbonyl complexes [33,34]. In spite of their inherently weak nature, $\mathrm{M}-\mathrm{CO}($ lone pair $) \cdots \pi^{*}$ interactions stabilize precise molecular conformations that maximize the overlap between the involved donor and acceptor orbitals in the interaction and can also provide a measure of stability to their crystal structures and lead to supramolecular architectures [35].

Therefore, the structural and computational studies of such interactions are of great interest and a new topic in the structural and computational chemistry of metal carbonyl complexes [36-38]. In continuation of our work on synthesis, characterization, structural chemistry, and computational studies of transition metal-carbonyl complexes [39,40], we here report the synthesis, spectroscopic, structural and computational studies of new $\operatorname{Re}(\mathrm{I})$-tricarbonyl bromo complexes bearing 1,4-diazabutadiene as non-heterocyclic diimine ligands, namely: $N, N$-bis(2,4-dimethylbenzene)-1,4-diazabutadiene, 2,4-Me ${ }_{2} D A B \quad(\mathbf{1}) ; \quad N, N$-bis(2,4-dimethylbenzene)-2,3-dimethyl-1,4-diazabutadiene, $\quad{ }^{2,4-M e}{ }_{2} D A B^{M e}$ (2); $\quad N, N$-bis(2,4,6-trimethylbenzene)-1,4-diazabutadiene, $\quad 2,4,6-M e{ }_{3} D A B \quad$ (3); $\quad$ and $N, N$-bis(2,6-diisopropylbenzene)-1,4-diazabutadiene, ${ }^{2,6-i p r}{ }_{2} D A B$ (4). The solid-state structures of complexes 1-4 were confirmed by single-crystal X-ray diffraction, and the intra- and intermolecular interaction results from $X$-ray diffraction were elucidated by NCI and NBO calculations.

\section{Experimental}

\subsection{General Methods}

All chemicals used were analytical reagent grade. All solvents purchased from Merck were reagent grade and purified by standard techniques where required. $\mathrm{CH}_{3} \mathrm{CN}$ was distilled over $\mathrm{P}_{2} \mathrm{O}_{5}$ for synthesis. Commercially available $\operatorname{Re}(\mathrm{CO})_{5} \mathrm{Br}$ from Aldrich was used as received. The ${ }^{1} \mathrm{H}-\mathrm{NMR}$ and ${ }^{13} \mathrm{C}$-NMR $(125 \mathrm{MHz})$ spectra were recorded using a BRUKER AVANCE $500 \mathrm{MHz}$ spectrometer in $\mathrm{CDCl}_{3}$. IR spectra in the region of $4000-400 \mathrm{~cm}^{-1}$ were recorded in $\mathrm{KBr}$ pellets with a Shimadzu IRPrestige-21 FTIR spectrophotometer. Electronic absorption spectra were measured with a Rayleh 5E spectrophotometer in dichloromethane solutions. The elemental analyses were done using a LECO CHNS instrument. The preparation of all $\operatorname{Re}(\mathrm{I})$ complexes (Scheme 1) was achieved using the previously reported procedure based on phenanthroline-type ligands, except that DAB ligands were used [41]. The FTIR, ${ }^{1} \mathrm{H}-\mathrm{NMR}$, and ${ }^{13} \mathrm{C}\left\{{ }^{1} \mathrm{H}\right\}$-NMR spectra of the complexes are listed in the supplementary materials. The DAB ligands, L1-L4, were prepared by condensation of glyoxal or diacetyl with the appropriate primary amine, according to literature procedures (see Supporting Information) [42]. The analytical data on L1-L4 are shown in Figures S1-S8. 


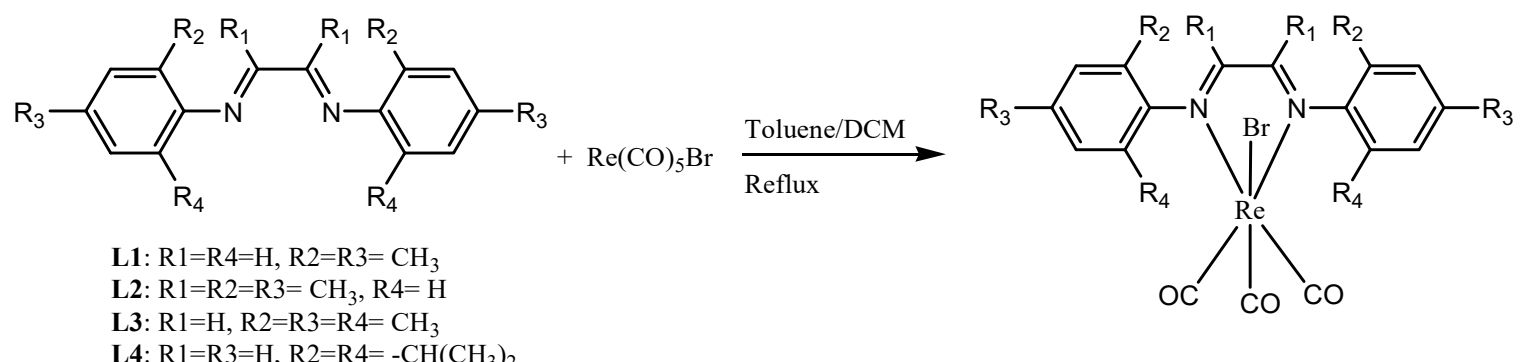

Scheme 1. Synthesis pathway of complexes 1-4.

[(2,4-Me $\left.\left.{ }_{2} \mathrm{DAB}\right) \operatorname{Re}(\mathrm{CO})_{3} \mathrm{Br}\right](\mathbf{1})$. A mixture of $\operatorname{Re}(\mathrm{CO})_{5} \mathrm{Br}(203 \mathrm{mg}, 0.5 \mathrm{mmol})$ and ${ }^{2,4-\mathrm{Me}}{ }_{2} \mathrm{DAB}$ (132 $\mathrm{mg}, 0.5 \mathrm{mmol})$ in a mixture of $\mathrm{CH}_{2} \mathrm{Cl}_{2}(10 \mathrm{~mL})$ and toluene $(30 \mathrm{~mL})$ was heated at reflux for $4 \mathrm{~h}$ to give a dark-brown solution. The volume of the solution was reduced to $10 \mathrm{~mL}$ and by addition of cold n-hexane the complex was precipitated. The crude material recrystallized from $\mathrm{CH}_{2} \mathrm{Cl}_{2} /$ hexane to give the complex as a pure dark-brown microcrystalline powder. Anal. Calc. for $\mathrm{C}_{13} \mathrm{H}_{8} \mathrm{BrN}_{2} \mathrm{O}_{3} \operatorname{Re}: \mathrm{C}, 41.05$; $\mathrm{H}, 3.28 ; \mathrm{N}, 4.56$. Found: $\mathrm{C}, 41.04 ; \mathrm{H}, 3.25, \mathrm{~N}, 4.58 .{ }^{1} \mathrm{HNMR}\left(\delta_{\mathrm{ppm}}, \mathrm{CDCl}_{3}\right): 2.40\left(\mathrm{~s}, 6 \mathrm{H}, 2-\mathrm{CH}_{3}\right), 2.41(\mathrm{~s}$, $\left.6 \mathrm{H}, 4-\mathrm{CH}_{3}\right), 7.10-7.46\left(\mathrm{~m}, 6 \mathrm{H}\right.$, aromatic protons), 8.61 (s, $2 \mathrm{H}$, iminic protons). $\left.{ }^{13} \mathrm{C}^{1} \mathrm{H}\right\}-\mathrm{NMR}(125 \mathrm{MHz}$, $\left.\mathrm{CDCl}_{3}\right)$ : $18.06\left(2-\mathrm{CH}_{3}\right), 21.05\left(4-\mathrm{CH}_{3}\right), 123.14(\mathrm{C} 6), 127.12$ (C2), 127.55 (C5), 132.14 (C3), $138.64(\mathrm{C} 4)$, 148.85 (C1), 165.02 (iminic carbon), $182.94\left(\mathrm{CO}_{\mathrm{ax}}\right), 194.79\left(\mathrm{CO}_{\mathrm{eq}}\right) . \mathrm{IR}\left(\mathrm{KBr}, \mathrm{cm}^{-1}\right)$ : $v_{\max } 2020\left(\mathrm{CO}_{\mathrm{ax}}\right)$, 1938 and 1890 (CO ${ }_{\text {eq }}$ ). UV-Vis in DCM: $\lambda_{\max }(\varepsilon)$ : 230 (16750), 330 (3207), 394 (4387), 505 (3918).

$\left[\left(2,4-\mathrm{Me}_{2} \mathrm{DAB}^{\mathrm{Me}}\right) \operatorname{Re}(\mathrm{CO})_{3} \mathrm{Br}\right](2)$. The complex was prepared by a procedure similar to $\mathbf{1}$ using

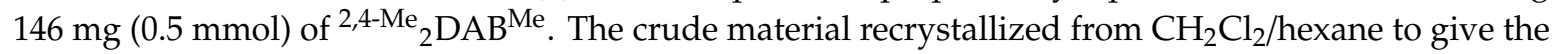
complex as a pure dark-brown microcrystalline powder. Anal. Calc. for $\mathrm{C}_{17} \mathrm{H}_{12} \mathrm{BrN}_{2} \mathrm{O}_{3} \mathrm{Re}$ : C, 42.99; $\mathrm{H}, 3.76 ; \mathrm{N}, 4.36$. Found; C, 42.97; H, 3.75; N, 4.39. ${ }^{1} \mathrm{HNMR}\left(\delta_{\mathrm{ppm}}, \mathrm{CDCl}_{3}\right): 2.10\left(\mathrm{~s}, 6 \mathrm{H}, 2-\mathrm{CH}_{3}\right), 2.20$ $\left(\mathrm{m}, 6 \mathrm{H}, 4-\left(\mathrm{CH}_{3}\right)\right), 2.35\left(\mathrm{~s}, 6 \mathrm{H}, 7-\mathrm{CH}_{3}\right), 7.0-7.5\left(\mathrm{~m}, 6 \mathrm{H}\right.$, aromatic protons). ${ }^{13} \mathrm{C}\left\{{ }^{1} \mathrm{H}\right\}-\mathrm{NMR}(125 \mathrm{MHz}$, $\left.\mathrm{CDCl}_{3}\right)$ : $17.02\left(2-\mathrm{CH}_{3}\right), 20.41\left(4-\mathrm{CH}_{3}\right), 20.97\left(7-\mathrm{CH}_{3}\right), 121.37$ (C6), 126.09 (C2), 128.36 (C5), 132.16 (C3), 137.31 (C4), 146.39 (C1), 174.97 (iminic carbon), $185.01\left(\mathrm{CO}_{\mathrm{ax}}\right), 195.28\left(\mathrm{CO}_{\mathrm{eq}}\right) . \mathrm{IR}\left(\mathrm{KBr}, \mathrm{cm}^{-1}\right)$ : $v_{\max } 2019$ $\left(\mathrm{CO}_{\mathrm{ax}}\right), 1825$ and 1896 (CO $\mathrm{Cq}_{\mathrm{eq}}$. UV-Vis in DCM: $\lambda_{\max },(\varepsilon): 231$ (36301), 460 (6571).

$\left[\left(2,4,6-\mathrm{Me}_{3} \mathrm{DAB}\right) \operatorname{Re}(\mathrm{CO})_{3} \mathrm{Br}\right](3)$. The complex was prepared by a procedure similar to 1 using

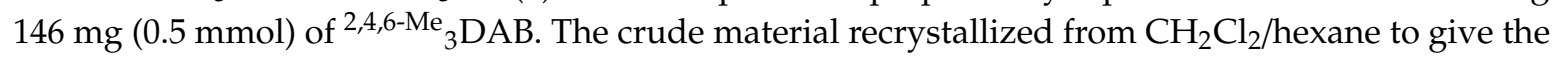
complex as a pure dark-brown microcrystalline powder. Anal. Calc. for $\mathrm{C}_{17} \mathrm{H}_{12} \mathrm{BrN}_{2} \mathrm{O}_{3} \mathrm{Re}$ : C, 42.99; $\mathrm{H}, 3.76 ; \mathrm{N}, 4.36$. Found; $\mathrm{C}, 42.95 ; \mathrm{H}, 3.77 ; \mathrm{N}, 4.38 .{ }^{1} \mathrm{HNMR}\left(\delta_{\mathrm{ppm}}, \mathrm{CDCl}_{3}\right): 2.28\left(\mathrm{~s}, 6 \mathrm{H}, 6-\mathrm{CH}_{3}\right), 2.37$ (s, $\left.6 \mathrm{H}, 2-\mathrm{CH}_{3}\right), 2.60\left(\mathrm{~s}, 6 \mathrm{H}, 4-\mathrm{CH}_{3}\right), 7.0-7.28(\mathrm{~m}, 4 \mathrm{H}$, aromatic protons), 8.69 (s, 2H, iminic protons). ${ }^{13} \mathrm{C}\left\{{ }^{1} \mathrm{H}\right\}-\mathrm{NMR}\left(125 \mathrm{MHz}, \mathrm{CDCl}_{3}\right): 19.03\left(6-\mathrm{CH}_{3}\right), 20.77\left(2-\mathrm{CH}_{3}\right), 20.89\left(4-\mathrm{CH}_{3}\right), 128.29(\mathrm{C} 6), 129.64(\mathrm{C} 5)$, 129.94 (C2), 130.25 (C3), 137.97 (C4), 148.44 (C1), 165.88 (iminic carbon), 183.89 (CO $\left.\mathrm{CO}_{\mathrm{ax}}\right), 194.17$ (CO eq). IR $\left(\mathrm{KBr}, \mathrm{cm}^{-1}\right)$ : $v_{\max } 2026\left(\mathrm{CO}_{\mathrm{ax}}\right), 1936$ and $1895\left(\mathrm{CO}_{\mathrm{eq}}\right)$. UV-Vis in DCM: $\lambda_{\max }(\varepsilon): 233$ (18406), 328 (2726), 400 (3847), 512 (5325).

$\left[\left({ }^{2,6-i p r}{ }_{2} \mathrm{DAB}\right) \operatorname{Re}(\mathrm{CO}){ }_{3} \mathrm{Br}\right](4)$. The complex was prepared by a procedure similar to 1 using $188 \mathrm{mg}$ ( $0.5 \mathrm{mmol})$ of ${ }^{2,6-\mathrm{ipr}}{ }_{2} \mathrm{DAB}$. The crude material recrystallized from $\mathrm{CH}_{2} \mathrm{Cl}_{2} /$ hexane to give the complex as a pure dark-brown microcrystalline powder. Anal. Calc. for $\mathrm{C}_{17} \mathrm{H}_{12} \mathrm{~N}_{3} \mathrm{O}_{5} \mathrm{Re}: \mathrm{C}, 47.93 ; \mathrm{H}, 4.99 ; \mathrm{N}$, 3.85. Found; $\mathrm{C}, 47.80 ; \mathrm{H}, 4.97 ; \mathrm{N}, 3.87 .{ }^{1} \mathrm{HNMR}\left(\delta_{\mathrm{ppm}}, \mathrm{CDCl}_{3}\right): 1.1\left(\mathrm{~m}, 12 \mathrm{H}, 8-\left(\mathrm{CH}_{3}\right)_{2}\right), 1.35(\mathrm{~m}, 12 \mathrm{H}$, 9- $\left.\left(\mathrm{CH}_{3}\right)_{2}\right), 2.75(\mathrm{~m}, 2 \mathrm{H}$, isopropyl protons $(8-\mathrm{CH})), 4(\mathrm{~m}, 2 \mathrm{H}$, isopropyl protons $(9-\mathrm{CH})), 7.1-7.4(\mathrm{~m}, 6 \mathrm{H}$, aromatic protons), 8.7 (s, $2 \mathrm{H}$, iminic protons). ${ }^{13} \mathrm{C}\left\{{ }^{1} \mathrm{H}\right\}-\mathrm{NMR}\left(125 \mathrm{MHz}, \mathrm{CDCl}_{3}\right): 23.18$ and 26.44 and 27.08 and 28.38 (methyl groups), 28.55 (isopropyl carbon), 124.19 (C5), 124.91 (C3), 129.09 (C4), 139.54 (C6), 141.01 (C2), 148.14 (C1), 166.22 (iminic carbon), $182.58\left(\mathrm{CO}_{\mathrm{ax}}\right), 194.19\left(\mathrm{CO}_{\mathrm{eq}}\right)$. IR $\left(\mathrm{KBr}, \mathrm{cm}^{-1}\right)$ : $v_{\max }$ $2027\left(\mathrm{CO}_{\mathrm{ax}}\right), 1930\left(\mathrm{CO}_{\mathrm{eq}}\right)$. UV-Vis in DCM: $\lambda_{\max }(\varepsilon)$ : 229 (9909), 332 (1295), 516 (3213).

\subsection{X-ray Crystallography}

Single crystals of 1-4, suitable for X-ray diffraction analysis, were grown by slow vapor diffusion of $n$-hexane into a dichloromethane solution of the complexes. X-ray intensity data were collected 
using the full-sphere routine by $\varphi$ and $\omega$ scans strategy on the Agilent SuperNova dual wavelength EoS S2 diffractometer with mirror monochromated Mo $K \alpha$ radiation $(\lambda=0.71073 \AA)$ for $\mathbf{1}, \mathbf{2}$, and 4 and with $\mathrm{Cu} K \alpha$ radiation for 3 . For all data collections, the crystals were cooled to 150(2) K using an Oxford diffraction Cryojet low-temperature attachment. The data reduction, including an empirical absorption correction using spherical harmonics, implemented in the SCALE3 ABSPACK scaling algorithm, was performed using the CrysAlisPro software package [43]. The crystal structures of 1-4 were solved by direct methods using the online version of AutoChem 2.0 in conjunction with the OLEX2 suite of programs [44] implemented in the CrysAlis software, and then refined by full-matrix least-squares (SHELXL-2018) on $F^{2}$ [45]. The non-hydrogen atoms were refined anisotropically. All of the hydrogen atoms were positioned geometrically in idealized positions and refined with the riding model approximation, with $U_{\text {iso }}(\mathrm{H})=1.2$ or $1.5 U_{\mathrm{eq}}(\mathrm{C})$. For the molecular graphics, the program SHELXTL was used [45]. All geometric calculations were carried out using the PLATON software [46]. The full crystal data, bond lengths and angles are listed in the supplementary materials.

\subsection{Computational Details}

Density functional theory (DFT) calculations have been performed using the Gaussian09 package [47] to perform geometry optimizations for vibrational frequencies and electronic structures of complexes 1-4. The structures of all complexes were optimized using the computational model (PBE1PBE) by combining the Perdew-Burke-Erzenrhof with the quasi-relativistic Stuttgart-Dresden (SDD) effective core pseudopotential (ECP) and corresponding set of basic functions for the Re atom and $6-31 \mathrm{G}^{*}$ (five pure $\mathrm{d}$ functions) for $\mathrm{C}, \mathrm{H}, \mathrm{N}, \mathrm{O}$, and $6-311+\mathrm{G}^{*}$ for $\mathrm{Br}[48,49]$.

\section{Results and Discussion}

\subsection{Synthesis and Characterization}

The new $\left[(\mathrm{NN}) \operatorname{Re}(\mathrm{CO})_{3} \mathrm{X}\right](\mathrm{NN}=$ diazabutadiene $)$ complexes were synthesized via substitution reaction from the DAB ligands and $\operatorname{Re}(\mathrm{CO})_{5} \mathrm{Br}$ in a mixture of $\mathrm{CH}_{2} \mathrm{Cl}_{2}$ and toluene under reflux condition. Complexes 1-4 were recrystallized from a mixture of $\mathrm{CH}_{2} \mathrm{Cl}_{2} / n$-hexane, and the purity of all complexes was confirmed by elemental analyses. The characteristic feature of the complexes incorporating $f a c-\left[\operatorname{Re}(\mathrm{CO})_{3}\right]^{+}$by losing two carbonyl groups in cis positions is the appearance of three intense carbonyl bands at about $2050-1880 \mathrm{~cm}^{-1}$, including a sharp intense band at about 2030-2050 $\mathrm{cm}^{-1}$ and two closely spaced lower energy bands consistent with the $\mathrm{A}^{\prime}(c i s), \mathrm{A}^{\prime \prime}(\mathrm{cis})$, and $\mathrm{A}^{\prime}$ (trans) modes expected in $C_{s}$ symmetry, with energy ordering $\mathrm{A}^{\prime}($ cis $)>\mathrm{A}^{\prime \prime}($ cis $)>\mathrm{A}^{\prime}($ trans $)$ as reported by Cotton-Karihanzel based on force field calculation [50-52]. As a normal trend, the position of the absorption bands is influenced by the electronic nature of the axial ligand. Normally, with the weakly donating ligands in the axial position, the $v(\mathrm{CO})$ is further increased. The electronic nature of the axial ligand $(\mathrm{X})$ in $f a c-\operatorname{Re}(\mathrm{CO})_{3}(\mathrm{NN})(\mathrm{X})$ complexes influences merging or splitting of the lower energy bands of the carbonyl groups. A stronger $\pi$-acceptor ligand in the basal plane shifts the $\mathrm{CO}$ stretching bands to higher frequencies. For complexes 2 and 4, by merging two lower energy bands, there seems to be an approximate $C_{3 v}$ spectroscopic symmetry, leading to a virtual " $E$ " band. The FT-IR spectra of complexes 1-4 are shown in Figures S9-S12. The stretching frequencies of the complexes are listed in the experimental section. The ${ }^{1} \mathrm{H}-\mathrm{NMR}$ and ${ }^{13} \mathrm{C}\left\{{ }^{1} \mathrm{H}\right\}-\mathrm{NMR}$ spectra of complexes $\mathbf{1 - 4}$ are shown in Figures S13-S20.

\subsection{X-ray Crystal Structures}

The solid-state structures of complexes 1-4 were determined by X-ray crystallography and are shown with their atom labelling scheme in Figure 1. Details of data collection and refinement parameters are given in Table 1. Selected bond lengths and angles for complexes 1-4 are listed in Table 2. The details of the hydrogen bonding interactions are listed in Table 3. 


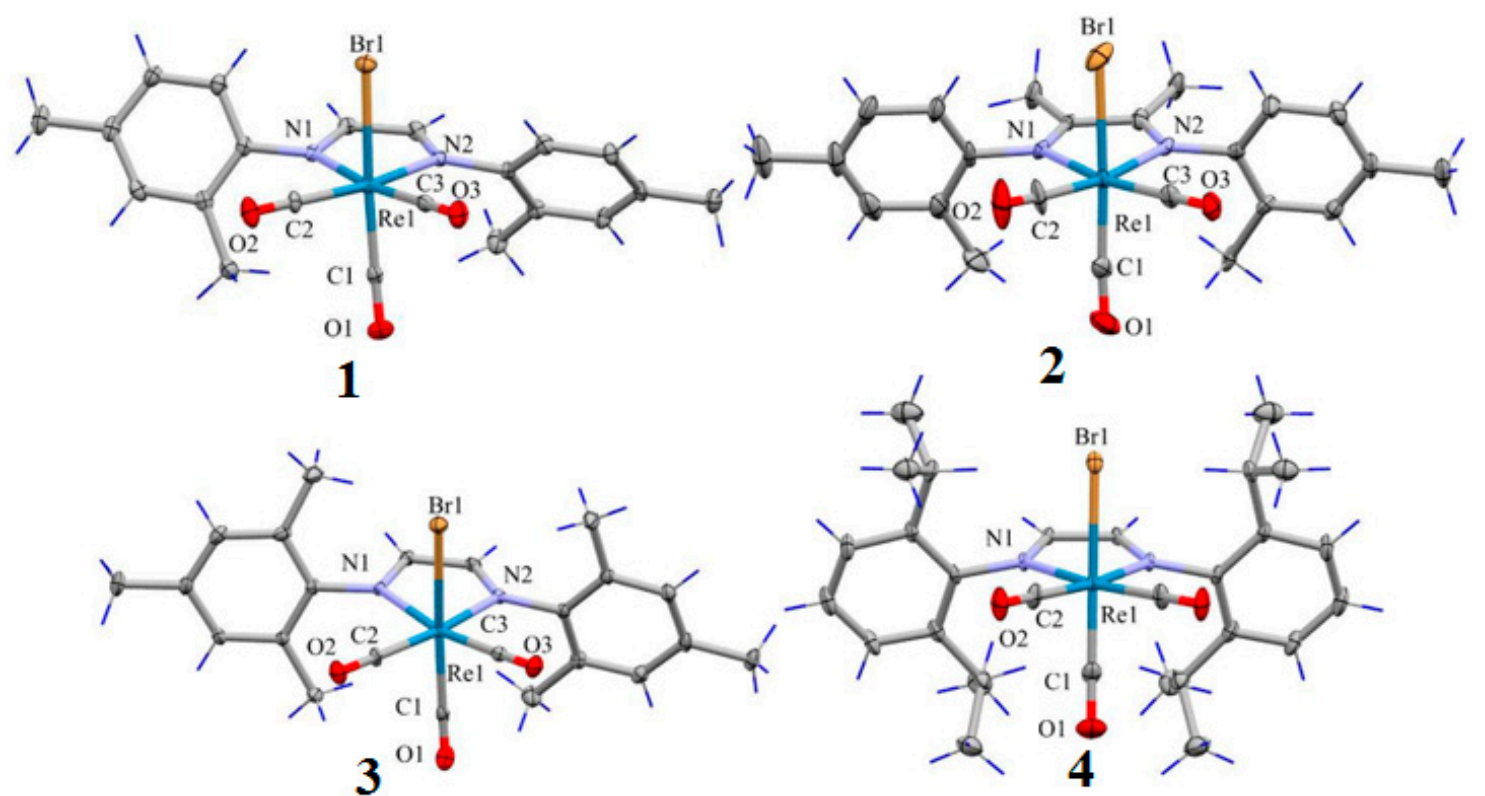

Figure 1. The molecular structure of complexes 1-4, showing $40 \%$ probability displacement ellipsoids and the atomic numbering ( $\mathrm{H}$ atoms are shown as blue wire). The symmetry code for unlabeled atoms in 4 is $x,-y+1 / 2$, $z$.

Table 1. Crystal data and refinement parameters of complexes 1-4.

\begin{tabular}{|c|c|c|c|c|}
\hline Complex & 1 & 2 & 3 & 4 \\
\hline Empirical Formula & $\mathrm{C}_{21} \mathrm{H}_{20} \mathrm{BrN}_{2} \mathrm{O}_{3} \mathrm{Re}$ & $\mathrm{C}_{23} \mathrm{H}_{24} \mathrm{BrN}_{2} \mathrm{O}_{3} \mathrm{Re}$ & $\mathrm{C}_{23} \mathrm{H}_{24} \mathrm{~N}_{2} \mathrm{O}_{3} \mathrm{Re}$ & $\mathrm{C}_{29} \mathrm{H}_{36} \mathrm{BrN}_{2} \mathrm{O}_{3} \mathrm{Re}$ \\
\hline Formula Mass & 614.50 & 642.55 & 642.55 & 726.71 \\
\hline Crystal Size (mm) & $0.10 \times 0.15 \times 0.25$ & $0.04 \times 0.08 \times 0.15$ & $0.10 \times 0.18 \times 0.35$ & $0.10 \times 0.18 \times 0.35$ \\
\hline Colour & Dark-brown & Dark-brown & Dark-brown & Dark-red \\
\hline Crystal System & Monoclinic & Triclinic & Orthorhombic & Orthorhombic \\
\hline Space Group & $P 2_{1} / n$ & $P-1$ & $\mathrm{Pbca}$ & Pnma \\
\hline$\theta_{\max }\left({ }^{\circ}\right)$ & 26 & 30.4 & 72.9 & 29.4 \\
\hline$a(\AA)$ & $7.3182(2)$ & $8.1105(3)$ & $14.0730(2)$ & $13.3103(5)$ \\
\hline$b(\AA)$ & $21.8786(9)$ & $8.3373(4)$ & $13.8361(2)$ & 21.7931(9) \\
\hline$c(\AA)$ & $13.0930(5)$ & $18.3651(11)$ & $23.2653(3)$ & $10.3165(5)$ \\
\hline$\alpha\left({ }^{\circ}\right)$ & 90 & $93.857(4)$ & 90 & 90 \\
\hline$\beta\left(^{\circ}\right)$ & $95.658(3)$ & $97.380(4)$ & 90 & 90 \\
\hline$\gamma\left({ }^{\circ}\right)$ & 90 & $104.588(4)$ & 90 & 90 \\
\hline$V\left(\AA^{3}\right)$ & 2086.13(13) & $1185.41(10)$ & $4530.11(11)$ & $2992.5(2)$ \\
\hline$Z$ & 4 & 2 & 8 & 4 \\
\hline$D_{\text {calc }}\left(\mathrm{Mg} / \mathrm{m}^{3}\right)$ & 1.957 & 1.800 & 1.884 & 1.613 \\
\hline$\mu\left(\mathrm{mm}^{-1}\right)$ & 7.764 & 6.836 & 12.775 & 5.462 \\
\hline$F(000)$ & 1176 & 620 & 2480 & 1432 \\
\hline Index Ranges & $-9 \leq \mathrm{h} \leq 8$ & $-11 \leq \mathrm{h} \leq 11$ & $-17 \leq \mathrm{h} \leq 11$ & $-18 \leq \mathrm{h} \leq 15$ \\
\hline & $-26 \leq \mathrm{k} \leq 26$ & $-11 \leq \mathrm{k} \leq 11$ & $-14 \leq \mathrm{k} \leq 17$ & $-27 \leq \mathrm{k} \leq 18$ \\
\hline & $-17 \leq 1 \leq 16$ & $-25 \leq 1 \leq 25$ & $-28 \leq 1 \leq 28$ & $-13 \leq 1 \leq 8$ \\
\hline $\begin{array}{l}\text { No. of Measured } \\
\text { Reflns. }\end{array}$ & 16734 & 23113 & 21739 & 8882 \\
\hline $\begin{array}{l}\text { No. of independent } \\
\text { reflns. } / R_{\text {int }}\end{array}$ & $4084 / 0.046$ & $6361 / 0.067$ & $4448 / 0.03$ & $3587 / 0.047$ \\
\hline No. of observed & 3477 & 5247 & 4228 & 2868 \\
\hline reflns. $I>2 \sigma(I)$ & 257 & 282 & 277 & 173 \\
\hline No. of parameters & 1.07 & 1.18 & 1.13 & 1.02 \\
\hline Goodness-of-fit (GOF) & 0.0261 & 0.0783 & 0.0288 & 0.0377 \\
\hline $\begin{array}{l}R_{1} \text { (observed data) } \\
w R_{2} \text { (all data) }\end{array}$ & 0.0574 & 0.1694 & 0.0726 & 0.0722 \\
\hline
\end{tabular}


Table 2. Selected bond lengths $(\AA)$ and angles $\left(^{\circ}\right)$ of $\mathbf{1}-\mathbf{4}$.

\begin{tabular}{lllll}
\hline Bond Lengths (Å) & $\mathbf{1}$ & $\mathbf{2}$ & $\mathbf{3}$ & $\mathbf{4}$ \\
\hline $\operatorname{Re}(1)-\mathrm{N}(1)$ & $2.180(3)[2.175]^{a}$ & $2.169(9) 2.173]$ & $2.182(3)[2.209]$ & $2.176(3)[2.223]$ \\
$\operatorname{Re}(1)-\mathrm{N}(2)$ & $2.150(4)[2.188]$ & $2.159(9)[2.173]$ & $2.179(3)[2.182]$ & - \\
$\operatorname{Re}(1)-\mathrm{C}(1)$ & $2.6114(6)[1.916]$ & $1.870(14)[1.911]$ & $1.994(4)[1.914]$ & $1.893(7)[1.927]$ \\
$\operatorname{Re}(1)-\mathrm{C}(2)$ & $1.933(4)[1.935]$ & $1.922(16)[1.936]$ & $1.934(4)[1.938]$ & $1.918(4)[1.951]$ \\
$\operatorname{Re}(1)-\mathrm{C}(3)$ & $1.923(4)[1.936]$ & $1.921(13)[1.936]$ & $1.924(4)[1.932]$ & - \\
$\mathrm{C}(1)-\mathrm{O}(1)$ & $1.141(5)[1.161]$ & $1.167(19)[1.163]$ & $1.002(6)[1.162]$ & $1.166(9)[1.165]$ \\
$\mathrm{C}(2)-\mathrm{O}(2)$ & $1.142(5)[1.156]$ & $1.15(2)[1.157]$ & $1.142(5)[1.156]$ & $1.148(5)[1.159]$ \\
$\mathrm{C}(3)-\mathrm{O}(3)$ & $1.141(5)[1.157]$ & $1.135(17)[1.157]$ & $1.145(5)[1.157]$ & - \\
$\operatorname{Re}(1)-\mathrm{Br}(1)$ & $2.6114(6)[2.655]$ & $2.6166(18)[2.668]$ & $2.6161(5)[2.664]$ & $2.6122(7)[2.712]$ \\
$\mathrm{Bond} \mathrm{Angles}\left({ }^{\circ}\right)$ & & & \\
$\mathrm{N}(1)-\operatorname{Re}(1)-\mathrm{N}(2)$ & $74.59(13)[74.03]$ & $73.3(4)[72.98]$ & $74.08(11)[74.11]$ & $75.62(12)[73.92]$ \\
$\mathrm{C}(1)-\operatorname{Re}(1)-\mathrm{N}(1)$ & $99.20(14)[92.51]$ & $95.5(5)[95.11]$ & $99.86(14)[98.94]$ & $96.53(18)[97.10]$ \\
$\mathrm{C}(2)-\operatorname{Re}(1)-\mathrm{N}(2)$ & $169.99(15)[170.0]$ & $171.2(6)[170.04]$ & $171.19(15)[171.16]$ & - \\
$\mathrm{N}(1)-\operatorname{Re}(1)-\mathrm{C}(3)$ & $171.97(16)$ & $168.9(5)[170.05]$ & $169.73(14)[168.91]$ & - \\
$\mathrm{N}(2)-\operatorname{Re}(1)-\mathrm{C}(3)$ & {$[170.22]$} & $95.4(8)[98.08]$ & $99.32(15)[97.47]$ & - \\
$\mathrm{C}(1)-\operatorname{Re}(1)-\mathrm{C}(3)$ & $99.45(15)[96.54]$ & $89.6(6)[89.98]$ & $88.05(17)[88.38]$ & - \\
$\mathrm{C}(2)-\operatorname{Re}(1)-\mathrm{C}(3)$ & $86.35(17)[91.24]$ & $89.1(6)[90.44]$ & $89.49(18)[91.17]$ & - \\
$\mathrm{C}(1)-\operatorname{Re}(1)-\mathrm{Br}(1)$ & $90.09(16)[90.51]$ & $177.7(4)[179.19]$ & $173.55(12)[174.76]$ & $176.1(2)[170.9]$ \\
\hline
\end{tabular}

Table 3. Hydrogen bonding interaction parameters in complexes 1-4.

\begin{tabular}{|c|c|c|c|c|}
\hline & $D-H \cdots A$ & 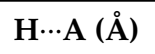 & 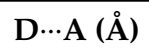 & D-H $\cdots A\left({ }^{\circ}\right)$ \\
\hline Complex 1 & $\mathrm{C}(11)-\mathrm{H}(11) \cdots \operatorname{Br}(1)^{\mathrm{i}}$ & 2.75 & $3.629(4)$ & 158 \\
\hline Complex 2 & $\mathrm{C}(13)-\mathrm{H}(16) \cdots \operatorname{Br}(1)^{\mathrm{ii}}$ & 2.92 & $3.841(12)$ & 168 \\
\hline \multirow[t]{4}{*}{ Complex 3} & $\mathrm{C}(11)-\mathrm{H}(11) \cdots \mathrm{O}(1)^{\prime \mathrm{iii}}$ & 2.45 & $3.375(6)$ & 162 \\
\hline & $\mathrm{C}(20)-\mathrm{H}(20 \mathrm{~B}) \cdots \operatorname{Br}(1)$ & 2.65 & $3.572(5)$ & 162 \\
\hline & $\mathrm{C}(21)-\mathrm{H}(21 \mathrm{~A}) \cdots \mathrm{O}(1)$ & 2.51 & $3.303(6)$ & 140 \\
\hline & $\mathrm{C}(23)-\mathrm{H}(23 \mathrm{C}) \cdots \operatorname{Br}(1)$ & 2.78 & $3.681(5)$ & 156 \\
\hline \multirow[t]{2}{*}{ Complex 4} & $\mathrm{C}(6)-\mathrm{H}(6) \cdots \mathrm{O}(2)^{\mathrm{iv}}$ & 2.52 & $3.451(6)$ & 177 \\
\hline & $\mathrm{C}(10)-\mathrm{H}(10) \cdots \operatorname{Br}(1)$ & 2.62 & $3.564(4)$ & 163 \\
\hline
\end{tabular}

Symmetry codes: (i) $1-\mathrm{x}, 1-\mathrm{y}, 1-\mathrm{z}$ (ii) $1+\mathrm{x}, 1+\mathrm{y}, \mathrm{z}$ (iii) $\frac{1}{2}+\mathrm{x}, \frac{1}{2}-\mathrm{y},-1 / 2+\mathrm{z}$ (iv) $1-\mathrm{x}, \frac{1}{2}+\mathrm{y},-1-\mathrm{z}$.

The geometry around the $\operatorname{Re}(\mathrm{I})$ is a distorted octahedron involving the carbonyl groups in facial arrangement, a DAB ligand and axial bromo group. In complex 2, the methyl group in the ortho position was disordered over two positions with a refined site-occupancy ratio of $0.81(2) / 0.19(2)$. The most significant angular distortion is associated with the bite angles of the DAB ligands $N(1)-\operatorname{Re}(1)-\mathrm{N}(2)$ in the range of $73.3(4)-75.62(12)^{\circ}$ which is due to the formation of the strained five-membered chelate ring. The trans angle $C(1)-\operatorname{Re}(1)-\operatorname{Br}(1)$ in $1-4$ falls in the range of $173.55(12)-177.7(4)^{\circ}$, respectively. The bond lengths, angles and coordination geometry of the crystal structures in 1-4 are similar to those structures reported previously $[53,54]$. There is only one report related to the crystal structure of 1,4-alkyldiazabutadiene, namely 1,4-di(tert-butyl) diazabutadiene, which shows significantly different $\mathrm{Re}-\mathrm{N}[2.170(15), 2.226(19) \AA], \mathrm{C} \equiv \mathrm{O}[1.13(3), 1.16(3)$, and 1.01(3) $\AA$ ] bond lengths compared to 1,4-aryldiazabutadiene, but the $\mathrm{Re}-\mathrm{Br}$ bond length is similar to complexes 1-4 [13]. The interesting feature of complexes $\mathbf{1}$ and $\mathbf{3}$ is the intermolecular $n \cdots \pi^{*}$ interactions which connects neighbouring molecules into a 1-D extended chain along the $a$ - and $b$-axis, respectively (Figures 2 and 3). As it is summarized in Table 3, the crystal packing of the complexes is consolidated mainly by the intermolecular non-classic $\mathrm{C}-\mathrm{H} \cdots \mathrm{O}$ and $\mathrm{C}-\mathrm{H} \cdots \mathrm{Br}$ hydrogen bonding. In complexes 1 and 4 , the intermolecular $\mathrm{C}-\mathrm{H} \cdots \mathrm{Br}$ and $\mathrm{C}-\mathrm{H} \cdots \mathrm{O}$ interactions form individual dimers in the crystal packing, respectively. In case of complexes 2 and 3, intermolecular $\mathrm{C}-\mathrm{H} \cdots \mathrm{Br}$ and $\mathrm{C}-\mathrm{H} \cdots \mathrm{O}$ interactions connect neighbouring molecules into an extended infinite chain along the $b$-axis, respectively. Figure 4 shows 
one-dimensional extended chain formation along the $a$-axis through intermolecular $\mathrm{C}-\mathrm{H} \cdots \mathrm{O}$ and $\mathrm{C}-\mathrm{H} \cdots \mathrm{Br}$ interactions in complex 4 .

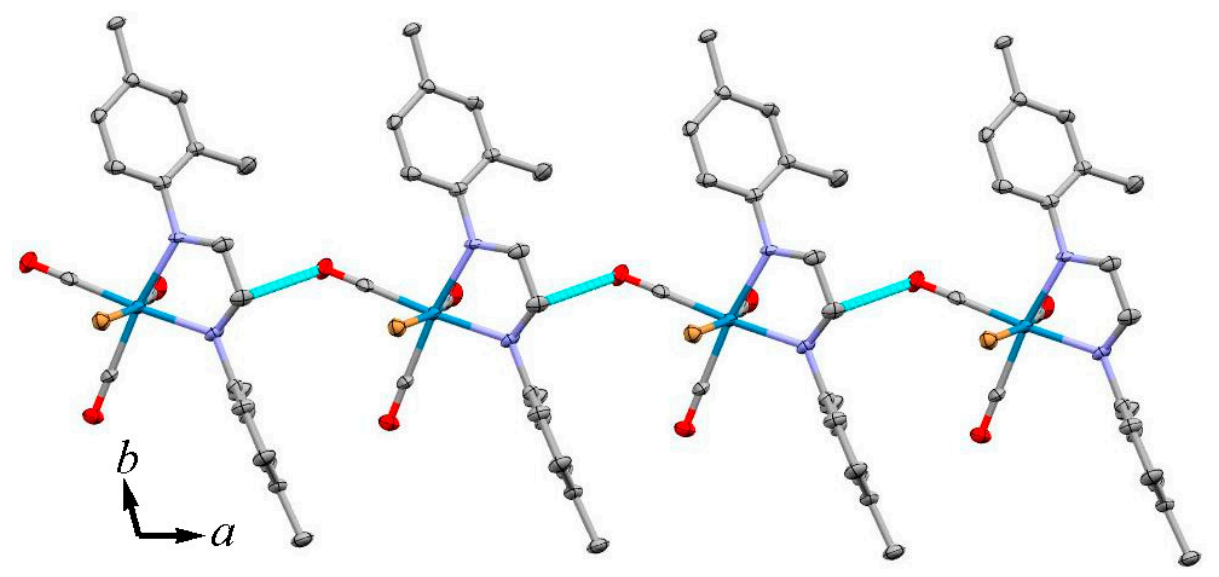

Figure 2. Part of the crystal packing of $\mathbf{1}$, showing one-dimensional extended chain formation along the $a$-axis through intermolecular $\mathrm{n} \rightarrow \pi^{*}$ interaction ( $\mathrm{H}$ atoms omitted for clarity).

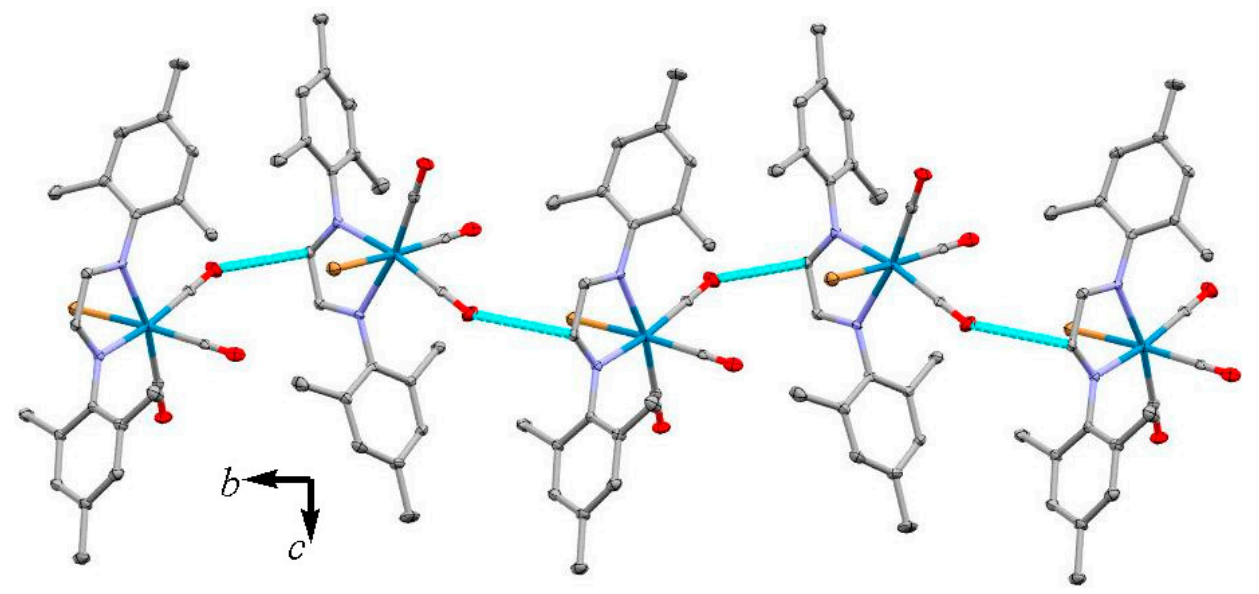

Figure 3. Part of the crystal packing of 3 , showing one-dimensional extended chain formation along the $b$-axis through intermolecular $\mathrm{n} \rightarrow \pi^{*}$ interaction ( $\mathrm{H}$ atoms omitted for clarity).

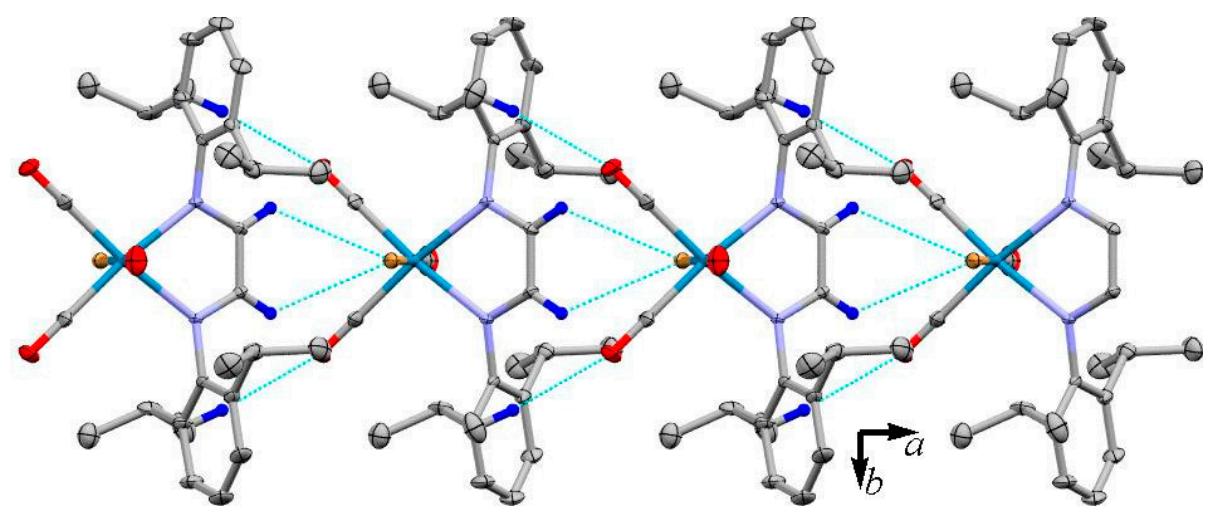

Figure 4. Part the crystal packing of 4 , showing one-dimensional extended chain formation along the $a$-axis through intermolecular $\mathrm{C}-\mathrm{H} \cdots \mathrm{O}$ and $\mathrm{C}-\mathrm{H} \cdots \mathrm{Br}$ interaction ( $\mathrm{H}$ atoms omitted for clarity).

\subsection{Non-Covalent Interaction Index and Natural Bond Orbitals (NBOs)}

Non-covalent interactions were evaluated using the non-covalent index (NCI) approach, which relies on the topological analysis of the electron density and its derivatives at low density regions based 
on the reduced density gradient (RDG) $[55,56]$. The NCI isosurface regions show both stabilizing and destabilizing weak interactions. These are distinguishable according to the total sign of the second eigenvalue of the Hessian $\left(\lambda_{2}\right)$ matrix, where the sign of the $\lambda_{2}$ quantity can vary accordingly and are thus suggested as a useful descriptor to characterize such situations. Negative values of the product given by $\rho^{*}$ sign $\left(\lambda_{2}\right)$, denote stabilizing interactions. Values close to zero account for weak interactions (van der Waals forces), while positive values account for weak repulsive cases. One of the main reasons to include the $\mathrm{Br}$ ligand in the axial position of the complexes was to increase the possibility of intra- and intermolecular interactions through halogen $\cdots$ halogen and halogen $\cdots$ oxygen bonding, since Br has a greater tendency to act as halogen bond acceptor compared to $\mathrm{Cl}$, because of the greater $\sigma$-hole [57]. Complexes 1, 3, and 4 showed some interesting intra- and intermolecular interactions which were investigated by non-covalent interaction index (NCI) and NBO calculations. The NCI analyses for single molecules were done based on the optimized structures, but in case of the dimer pairs they were calculated directly from the crystallographically generated dimers without optimization. The surface $\mathrm{NCI}$ analyses are depicted in Figures 5-8, revealing stabilizing weak non-covalent intramolecular interactions in single-molecule and intermolecular interactions between interacting pairs, respectively. On the other hand, to shed light on the nature and strength of the intra- and intermolecular interactions depicted by NCI calculations, NBO analysis of other suitable descriptors for bond analysis was used with more details. Natural bond orbital calculations were performed on 1, 3, and 4 with the same level of theory for molecular orbital calculations [58]. The NBO analysis shows that the attractive nature is associated with donor-acceptor orbital interactions in single molecules and between the pairs. Figure 5 shows the intermolecular interactions in $\mathbf{1}$ with contributions from the lone pair of oxygen in the carbonyl group and the $\pi^{*}$ of the imine functional group, $\mathrm{n}_{\mathrm{s}}(\mathrm{O} 3) \cdots \pi^{*}(\mathrm{C} 10=\mathrm{N} 1)$ and $\pi(\mathrm{C} 3 \equiv \mathrm{O} 3) \cdots \pi^{*}(\mathrm{C} 10=\mathrm{N} 1)$, with $0.47 \mathrm{kcal} \mathrm{mol}^{-1}$ according to the $\mathrm{NBO}$ analysis from second-order perturbation energy. The energy contribution of $n_{s}(\mathrm{O} 2) \cdots \pi^{*}(\mathrm{C} 8=\mathrm{C} 9)$ was negligible.

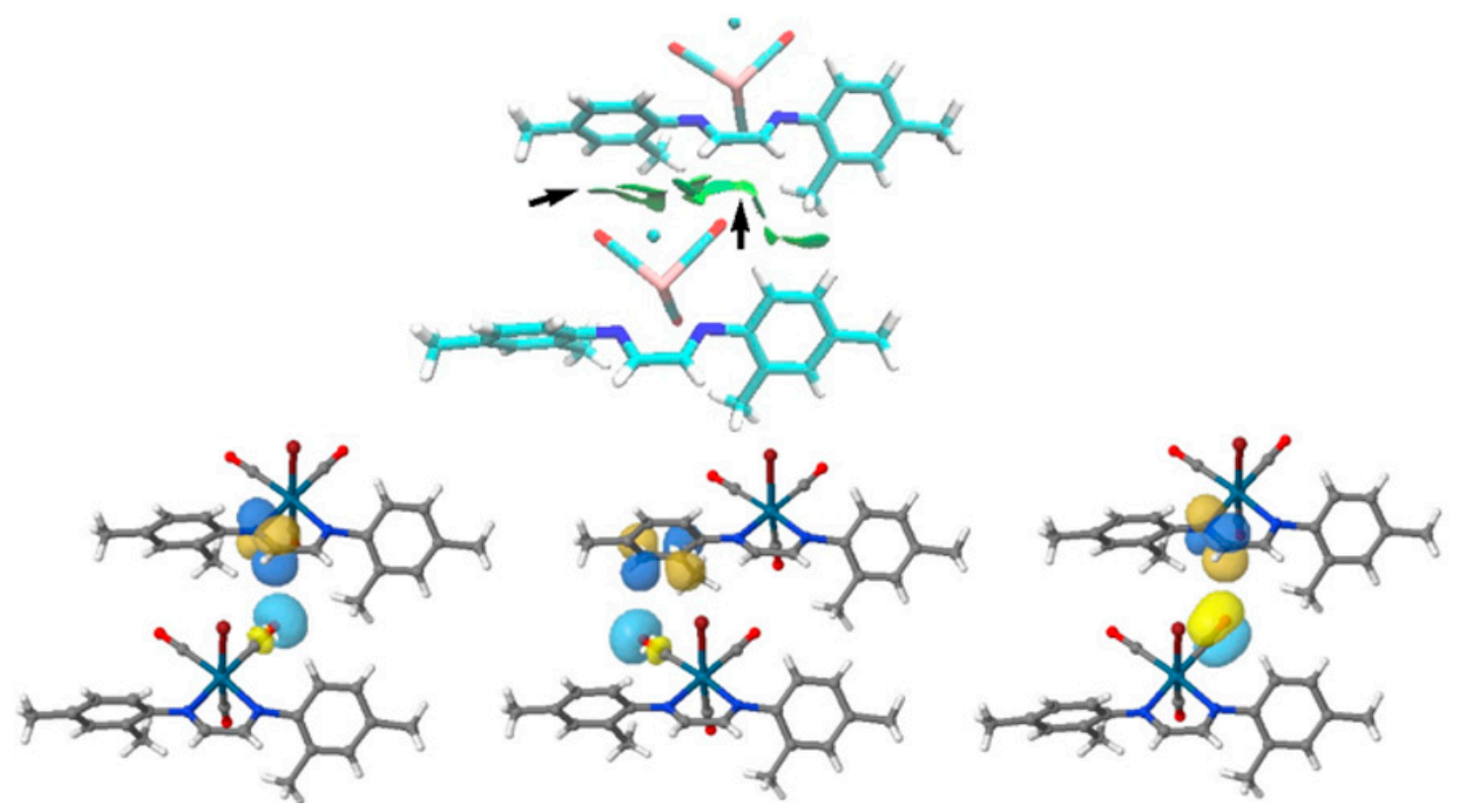

Figure 5. NCI plot of interacting dimer in $\mathbf{1}$ and the donor-acceptor interacting orbitals from NBO calculations. The area of $n \cdots \pi^{*}$ and $\pi \cdots \pi^{*}$ are shown in the NCI plot with arrows.

The NCI plot and NBO analyses of 3 are shown in Figure 6. The NCI plot shows interactions between the $\mathrm{C}-\mathrm{H}$ bond of the methyl group and $\mathrm{Br}[\mathbf{A}-\mathbf{H}]$ and the $\mathrm{C}-\mathrm{H}$ bond and the carbonyl group, $\mathbf{I}-\mathbf{L}$, in axial positions with light-blue color, confirming attractive interactions. These interactions are due to the overlap of the perpendicular occupied $\mathrm{s}$ and $\mathrm{p}$ orbitals of $\mathrm{Br}$ to the empty $\sigma^{*}$ orbital of the $\mathrm{C}-\mathrm{H}$ bond with overall energy release of $8.07 \mathrm{kcal} \mathrm{mol}^{-1}$, based on the NBO analysis from 
second-order perturbation energy. The contribution from $n_{p}(B r) \cdots \sigma^{*}(C-H), C-D$, was 2.48, 2.27, and $2.09 \mathrm{kcal} \mathrm{mol}^{-1}$, respectively.
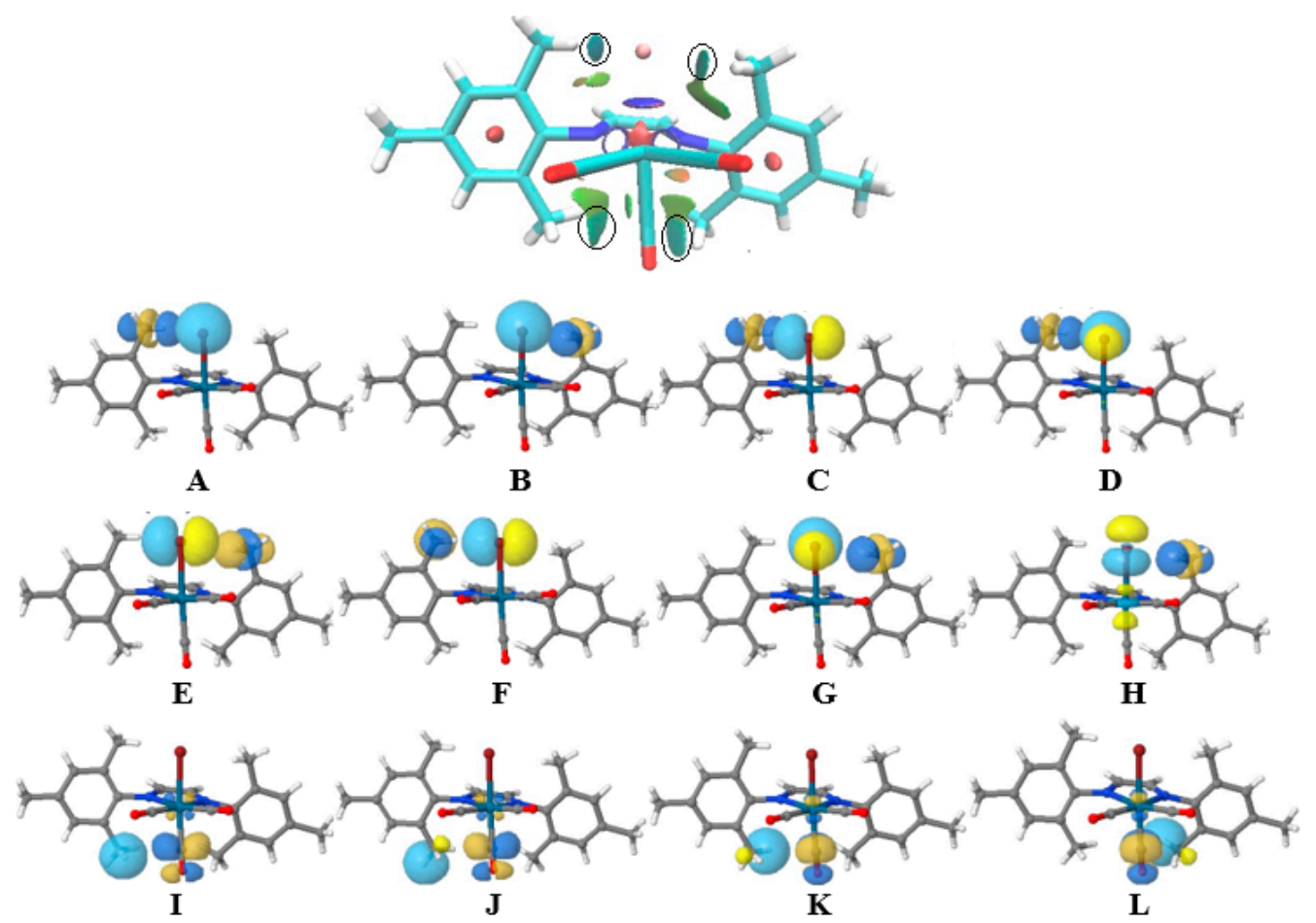

Figure 6. NCI plot of 3 and the representation of interacting donor-acceptor $n_{s}(\mathrm{Br}) \cdots \sigma^{*}(\mathrm{CH})$, A-B; $\mathrm{n}_{\mathrm{p}}(\mathrm{Br}) \cdots \sigma^{*}(\mathrm{CH}), \mathbf{C}-\mathbf{H} ; \sigma(\mathrm{CH}) \cdots \pi^{*}(\mathrm{CO}), \mathbf{I}-\mathbf{L}$; orbitals from NBO calculations.
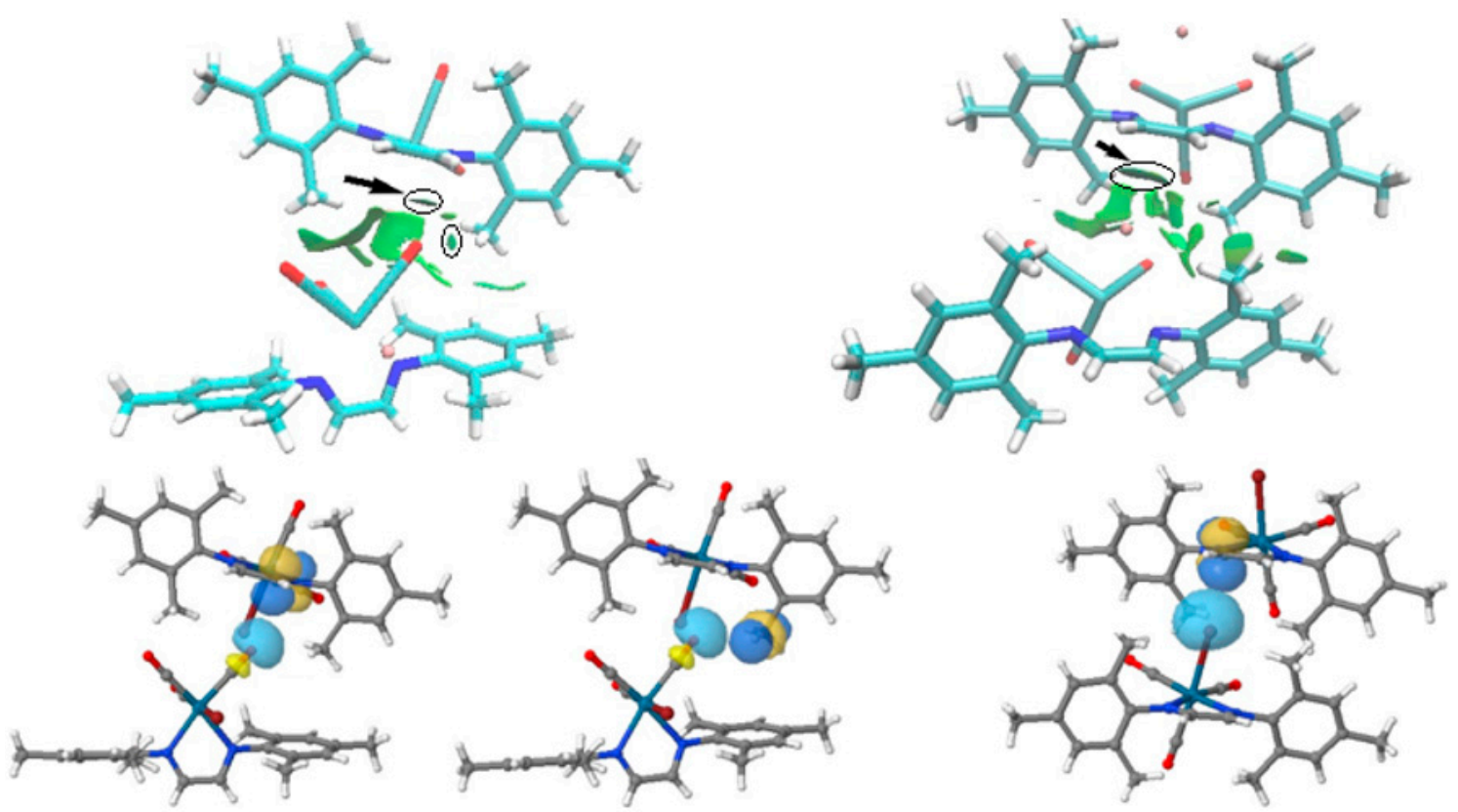

Figure 7. NCI plot of the interacting dimer in 3 and the representation of donor-acceptor interacting $\mathrm{n}(\mathrm{O}) \cdots \pi^{*}, \mathrm{n}(\mathrm{O}) \cdots \sigma^{*}$, and $\mathrm{n}(\mathrm{Br}) \cdots \pi^{*}$ orbitals from NBO calculations. The area is shown in the NCI plot with arrows. 

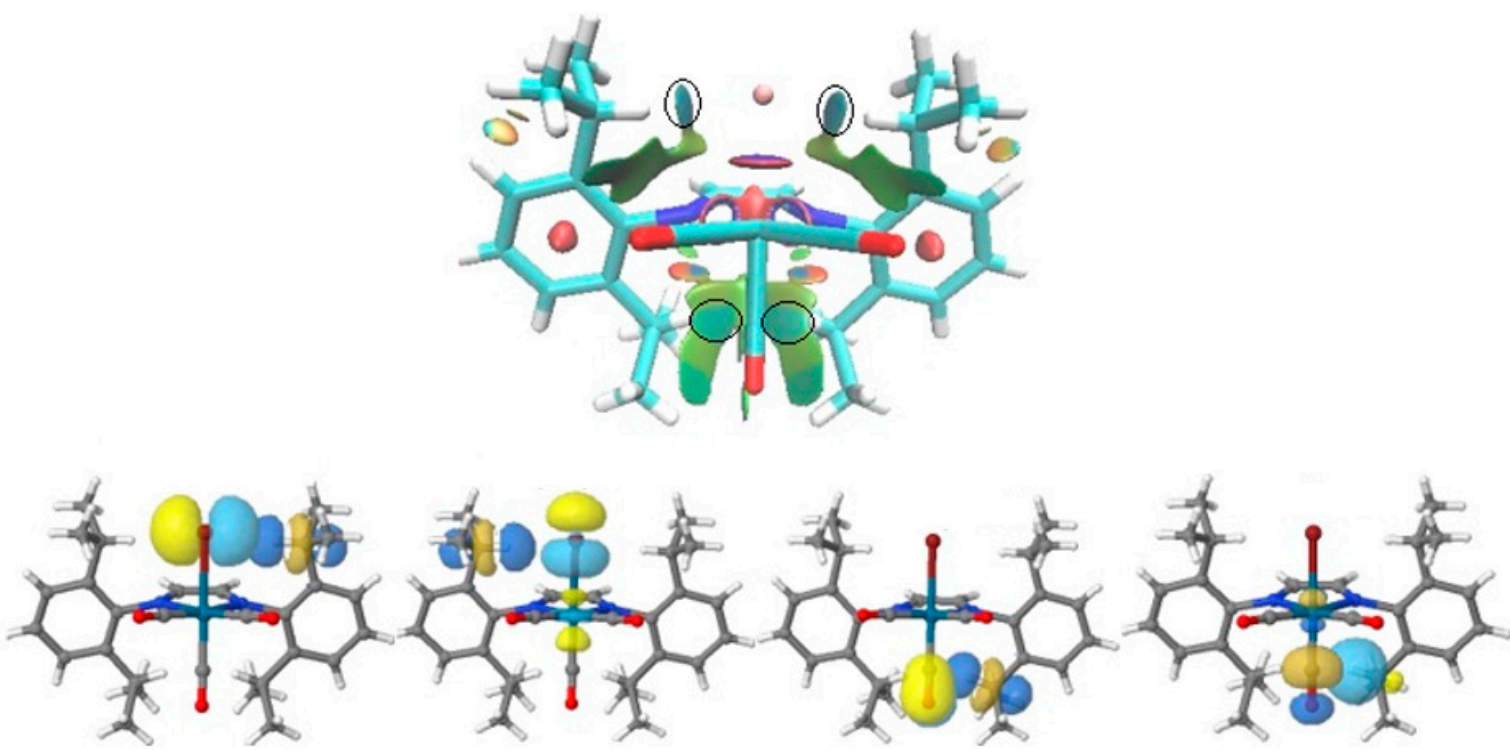

Figure 8. NCI plot of interacting dimer in 4 and the donor-acceptor interacting orbitals from NBO calculations through $\mathrm{n}_{\mathrm{p}}(\mathrm{Br}) \cdots \sigma^{*}, \mathrm{n}_{\mathrm{p}}(\mathrm{Br}) \cdots \sigma^{*}, \pi(\mathrm{CO}) \cdots \sigma^{*}, \sigma^{\cdots} \pi^{*}(\mathrm{CO})$ from left to right, respectively. The interaction area is shown with black circles.

On the other hand, the NCI plot and NBO calculations of the interaction pairs of 3 were also analyzed and depicted in Figure 7. The total energy release of the $n(O) \cdots \pi^{*}$ and $n(O) \cdots \sigma^{*}$ was $0.68 \mathrm{kcal} \mathrm{mol}^{-1}$, while the contribution from $\mathrm{n}(\mathrm{Br}) \cdots \pi^{*}$ was $0.31 \mathrm{kcal} \mathrm{mol}^{-1}$ based on second-order perturbation energy calculations.

The NCI plot and NBO analyses of 4 are shown in Figure 8. The NCI plot shows some intramolecular interactions among the $\mathrm{Br}$, isopropyl and $\mathrm{CO}$ groups with green-blue color, confirming attractive interaction. The NBO study confirms the $\mathrm{n}_{\mathrm{p}}(\mathrm{Br}) \cdots \sigma^{*}, \pi(\mathrm{CO}) \cdots \sigma^{*}$, and $\sigma^{\cdots} \pi^{*}(\mathrm{CO})$ interactions in 4 with energy releases of 3.46, 0.28 and $0.44 \mathrm{kcal} \mathrm{mol}^{-1}$ based on the NBO analysis from second-order perturbation energy, respectively.

\section{Conclusions}

In this paper, we have described the synthesis, characterization, structural and full computational studies of four bromide- tricarbonyl Re(I) complexes 1-4, bearing substituted diazabutadiene ligands. The molecular structures of the complexes were established by single-crystal X-ray diffraction, feature the metal in a distorted octahedral environment with facial arrangement of the carbonyl groups in the complexes, which was also confirmed by FT-IR spectroscopy. The nature and energy of the intermolecular $\mathrm{n}(\mathrm{O}) \cdots \pi^{*}$ interactions between carbonyl-bound metal and $\pi^{*}$ of benzene ring and imine segments in 1 and $\mathrm{n}(\mathrm{O}) \cdots \pi^{*}$ and $\mathrm{n}(\mathrm{Br}) \cdots \pi^{*}$ in $\mathbf{3}$ were investigated in detail. The presence of such interactions was also confirmed by NCI index based on colour codes. The complexes 3 and 4 showed interesting intramolecular $\mathrm{n}_{\mathrm{p}}(\mathrm{Br}) \cdots \sigma^{*}$ interactions, which stabilized the internal geometry of the coordinated ligand around the metal center.

Supplementary Materials: The following are available online at http://www.mdpi.com/2073-4352/10/4/267/s1. CCDC 1962581(1), 1962582(2), 1962583(3), and 1962580(4) contain the supplementary crystallographic data for this paper. These data can be obtained free of charge from The Cambridge Crystallographic Data Centre via www.ccdc.cam.ac.uk/data_request/cif. FT-IR of complexes 1-4, the crystal packing of complexes 1-4, some of the important frontier molecular orbitals of 5, and crystallographic data of complexes 1-4 in CIF format. Figure S1. The ${ }^{11} \mathrm{H}-\mathrm{NMR}$ spectrum of complex L1; Figure S2. The ${ }^{13} \mathrm{C}\left\{{ }^{1} \mathrm{H}\right\}-\mathrm{NMR}$ spectrum of complex L1; Figure S3. The ${ }^{1} \mathrm{H}-\mathrm{NMR}$ spectrum of complex L2; Figure S4. The ${ }^{13} \mathrm{C}\left\{{ }^{1} \mathrm{H}\right\}-\mathrm{NMR}$ spectrum of complex L2; Figure S5. The ${ }^{1} \mathrm{H}-\mathrm{NMR}$ spectrum of complex L3; Figure S6. The $\left.{ }^{13} \mathrm{C}^{1} \mathrm{H}\right\}-\mathrm{NMR}$ spectrum of complex L3; Figure S7. The ${ }^{1} \mathrm{H}-\mathrm{NMR}$ spectrum of complex L4; Figure S8. The ${ }^{13} \mathrm{C}\left\{{ }^{1} \mathrm{H}\right\}-\mathrm{NMR}$ spectrum of complex L4; Figure S9. The FTIR spectrum of 1 in $\mathrm{KBr}$ pellet; Figure S10. The FTIR spectrum of 2 in $\mathrm{KBr}$ pellet; Figure S11. The FTIR spectrum of 3 in KBr pellet; Figure S12. The FTIR spectrum of 4 in KBr pellet; Figure S13. The ${ }^{1} \mathrm{H}-\mathrm{NMR}$ spectrum of complex 
1; Figure S14. The ${ }^{13} \mathrm{C}\left\{{ }^{1} \mathrm{H}\right\}-\mathrm{NMR}$ spectrum of complex 1; Figure S15. The ${ }^{1} \mathrm{H}-\mathrm{NMR}$ spectrum of complex 2; Figure S16. The ${ }^{13} \mathrm{C}\left\{{ }^{1} \mathrm{H}\right\}-\mathrm{NMR}$ spectrum of complex 2; Figure S17. The ${ }^{1} \mathrm{H}-\mathrm{NMR}$ spectrum of complex 3 ; Figure S18. The ${ }^{13} \mathrm{C}\left\{{ }^{1} \mathrm{H}\right\}-\mathrm{NMR}$ spectrum of complex 3; Figure S19. The ${ }^{1} \mathrm{H}-\mathrm{NMR}$ spectrum of complex 4; Figure S20. The ${ }^{13} \mathrm{C}\{1 \mathrm{H}\}-\mathrm{NMR}$ spectrum of complex 4 .

Author Contributions: Manuscript preparation, X-ray structure determination, final structure analysis, and final editing of manuscript: R.K.; Synthesis and spectroscopic characterization of the complexes, manuscript review A.K. All authors have read and agreed to the published version of the manuscript.

Funding: This research was funded by Sharif University of Technology Research Council for financial support.

Conflicts of Interest: The funder had no role in the design of the study and in the decision to publish the results.

\section{References}

1. Ehlers, A.W.; Dapprich, S.; Vyboishchikov, S.F.; Frenking, G. Structure and Bonding of the Transition-Metal Carbonyl Complexes $\mathrm{M}(\mathrm{CO}) 5 \mathrm{~L}(\mathrm{M}=\mathrm{Cr}, \mathrm{Mo}, \mathrm{W})$ and $\mathrm{M}(\mathrm{CO})_{3} \mathrm{~L}\left(\mathrm{M}=\mathrm{Ni}, \mathrm{Pd}, \mathrm{Pt} ; \mathrm{L}=\mathrm{CO}, \mathrm{SiO}, \mathrm{CS}, \mathrm{N}_{2}, \mathrm{NO}^{+}\right.$, $\left.\mathrm{CN}^{-}, \mathrm{NC}^{-}, \mathrm{HCCH}, \mathrm{CCH}_{2}, \mathrm{CH}_{2}, \mathrm{CF}_{2}, \mathrm{H}_{2}\right)$. Organometallics 1996, 15, 105-117. [CrossRef]

2. Lee, A.J. Luminescence properties of organometallic complexes. Chem. Rev. 1987, 87, 711-743.

3. Farrell, I.R.; Vlcek, A., Jr. Mechanisms of ultrafast metal-ligand bond splitting upon MLCT excitation of carbonyl-diimine complexes. Coord. Chem. Rev. 2000, 208, 87-101. [CrossRef]

4. Striplin, D.R.; Crosby, G.A. Photophysical investigations of rhenium(I)Cl(CO)3(phenanthroline) complexes. Coord. Chem. Rev. 2001, 211, 163-175. [CrossRef]

5. Collin, J.P.; Sauvage, J.P. Electrochemical reduction of carbon dioxide mediated by molecular catalysts. Coord. Chem. Rev. 1989, 93, 245-268. [CrossRef]

6. Rossenaar, B.R.; Hartl, F.; Stufkens, D.J. Reduction of $\left[\operatorname{Re}(X)(C O)_{3}\left(R^{\prime}-D A B\right)\right]\left(X=O^{-}, B r-; D A B=\right.$ Diazabutadiene; $\mathrm{R}^{\prime}=\mathrm{iPr}$, pTol, pAn) and $\left[\operatorname{Re}(\mathrm{R})(\mathrm{CO})_{3}(\mathrm{iPr}-\mathrm{DAB})\right](\mathrm{R}=\mathrm{Me}, \mathrm{Et}, \mathrm{Bz})$ Complexes: A Comparative (Spectro)electrochemical Study at Variable Temperatures. Inorg. Chem. 1996, 35, 6194-6203. [CrossRef]

7. Balzani, V.; Juris, A.; Venturi, M.; Campagna, S.; Serroni, S. Luminescent and Redox-Active Polynuclear Transition Metal Complexes. Chem. Rev. 1996, 96, 759-834. [CrossRef]

8. Slone, R.V.; Hupp, J.T. Synthesis, Characterization, and Preliminary Host-Guest Binding Studies of Porphyrinic Molecular Squares Featuring fac-Tricarbonylrhenium(I) Chloro Corners. Inorg. Chem. 1997, 36, 5422-5423. [CrossRef]

9. Nieto, S.; Perez, J.; Riera, L.; Riera, V.; Miguel, D. Non-covalent interactions between anions and a cationic rhenium diamine complex: Structural characterization of the supramolecular adducts. New J. Chem. 2006, 30, 838-843. [CrossRef]

10. Hevia, E.; Perez, J.; Riera, V.; Miguel, D.; Kassel, S.; Rheingold, A.L. New Synthetic Routes to Cationic Rhenium Tricarbonyl Bipyridine Complexes with Labile Ligands. Inorg. Chem. 2002, 41, 4673-4679. [CrossRef]

11. Machura, B.; Wolff, M.; Jaworska, M.; Lodowski, P.; Benoist, E.; Carrayon, C.; Saffon, N.; Kruszynski, R.; Mazurak, Z. Rhenium(I) carbonyl complex of 4,7-diphenyl-1,10-phenanthroline-Spectroscopic properties, $X$-Ray structure, theoretical studies of ground and excited electronic states. J. Organomet. Chem. 2011, 696, 3068-3075. [CrossRef]

12. Drozdz, A.; Bubrin, M.; Fiedler, J.; Zalis, S.; Kaim, W. ( $\alpha$-Diimine)tricarbonylhalorhenium complexes: The oxidation side. Dalton Trans. 2012, 41, 1013-1019. [CrossRef] [PubMed]

13. Grupp, A.; Bubrin, M.; Ehret, F.; Kvapilova, H.; Zalis, S.; Kaim, W. Oxidation and reduction response of $\alpha$-diimine complexes with tricarbonylrhenium halides and pseudohalides. J. Organomet. Chem. 2014, 751, 678-685. [CrossRef]

14. Kumar, A.; Sun, S.-S.; Lees, A.J. Photophysics and Photochemistry of Organometallic Rhenium Diimine Complexes. Top. Organomet. Chem. 2010, 29, 1-35.

15. Kirgan, R.A.; Sullivan, B.P.; Rillema, D.P. Photochemistry and Photophysics of Coordination Compounds: Rhenium. Top. Curr. Chem. 2007, 281, 45-100.

16. Kinghat, R.; Khatyr, A.; Knorr, M.; Kubicki, M.M.; Vigier, E.; Villafañe, F. Mono- and di-nuclear 2,3-diazabutadiene and 2-azabutadiene complexes of Rhenium(I): Syntheses, luminescence spectra and X-ray structures. Inorg. Chem. Commun. 2008, 11, 1060. [CrossRef]

17. Zou, W.; Chen, C. Influence of Backbone Substituents on the Ethylene (Co)polymerization Properties of a-diimine Pd(II) and Ni(II) Catalysts. Organometallics 2016, 35, 1794-1801. [CrossRef] 
18. Kong, S.; Song, K.; Liang, T.; Guo, C.-Y.; Sun, W.-H.; Redshaw, C. 18 Methylene-bridged bimetallic $\alpha$-diimino nickel(II) complexes: Synthesis and high efficiency in ethylene polymerization. Dalton Trans. 2013, 42, 9176-9178. [CrossRef]

19. Abakumov, G.A.; Druzhkov, N.O.; Egorova, E.N.; Kocherova, T.N.; Shavyrin, A.S.; Cherkasov, A.V. Intramolecular cyclization-decyclization of new sterically hindered diiminophenol. Synthesis and coordination abilities. RSC Adv. 2014, 4, 14495-14500. [CrossRef]

20. Egorova, E.N.; Druzhkov, N.O.; Shavyrin, A.S.; Cherkasov, A.V.; Abakumova, G.A.; Fedorov, A.Y. The group 13 metal complexes of stericallyhindered substituted iminophenol: Synthesis and structure. RSC Adv. 2015, 5, 19362-19367. [CrossRef]

21. Echeverría, J. The $\mathrm{n} \rightarrow \pi^{*}$ interaction in metal complexes. Chem. Commun. 2018, 54, 3061-3064. [CrossRef] [PubMed]

22. Burgi, H.B.; Dunitz, J.D.; Lehn, J.M.; Wipff, G. Stereochemistry of reaction paths at carbonyl centres. Tetrahedron 1974, 30, 1563-1572. [CrossRef]

23. Burgi, H.B.; Dunitz, J.D.; Shefter, E. Geometrical reaction coordinates. II. Nucleophilic addition to a carbonyl group. J. Am. Chem. Soc. 1973, 95, 5065-5067. [CrossRef]

24. Mooibroek, T.J.; Gamez, P.; Reedijk, J. Lone pair- $\pi$ interactions: A new supramolecular bond? CrystEngComm 2008, 10, 1501-1515. [CrossRef]

25. Jakobsche, C.E.; Choudhary, A.; Miller, S.J.; Raines, R.T. $\mathrm{n} \rightarrow \pi^{*}$ Interaction and $\left.\mathrm{n}\right)(\pi$ Pauli Repulsion Are Antagonistic for Protein Stability. J. Am. Chem. Soc. 2010, 132, 6651-6653. [CrossRef]

26. Kramer, K.J.; Choudhary, A.; Raines, R.T. Intimate Interactions with Carbonyl Groups: Dipole-Dipole or $\mathrm{n} \rightarrow \pi^{*}$ ? J. Org. Chem. 2013, 78, 2099-2103. [CrossRef]

27. Bartlett, G.J.; Newberry, R.W.; Van Veller, B.; Raines, R.T.; Woolfson, D.N. Interplay of Hydrogen Bonds and $\mathrm{n} \rightarrow \pi^{*}$ Interactions in Proteins. J. Am. Chem. Soc. 2013, 135, 18682-18688. [CrossRef]

28. Singh, S.K.; Das, A. The $\mathrm{n} \rightarrow \pi^{*}$ interaction: A rapidly emerging non-covalent interaction. Phys. Chem. Chem. Phys. 2015, 17, 9596-9612. [CrossRef]

29. Velásquez, J.D.; Echeverría, J.; Alvarez, S. Effect of the Substituents on the Nature and Strength of Lone-Pair-Carbonyl Interactions in Acyl Halides. Cryst. Growth Des. 2019, 11, 6511-6518. [CrossRef]

30. Newberry, R.W.; Raines, R.T. The $\mathrm{n} \rightarrow \pi^{*}$ Interaction. Acc. Chem. Res. 2017, 50, 1838-1846. [CrossRef]

31. Doppert, M.T.; van Overeem, H.; Mooibroek, T.J. Intermolecular $\pi$-hole/ $\mathrm{n} \rightarrow \pi^{*}$ interactions with carbon monoxide ligands in crystal structures. Chem. Commun. 2018, 54, 12049-12052. [CrossRef] [PubMed]

32. van der Werve Ad, R.; van Dijk, Y.R.; Mooibroek, T.J. $\pi$-Hole/n $\rightarrow \pi^{*}$ interactions with acetonitrile in crystal structures. Chem. Commun. 2018, 54, 10742-10745. [CrossRef] [PubMed]

33. Zukerman-Schpector, J.; Haiduc, I.; Tiekink, E.R.T. The metal-carbonyl $\cdots \pi($ aryl) interaction as a supramolecular synthon for the stabilisation of transition metal carbonyl crystal structures. Chem. Commun. 2011, 47, 12682-12684. [CrossRef] [PubMed]

34. Zukerman-Schpector, J.; Haidu, I.; Tiekink, E.R.T. Supramolecular Self-assembly of Transition Metal Carbonyl Molecules Through M-CO(Lone Pair) ... $\pi$ (Arene) Interactions. Adv. Organomet. Chem. 2012, 60, 49-92.

35. Wan, C.-Q.; Chen, X.-D.; Mak, T.C.W. Supramolecular frameworks assembled via intermolecular lone pair-aromatic interaction between carbonyl and pyridyl groups. CrystEngComm 2008, 10, 475-478. [CrossRef]

36. Echeverría, J. Intermolecular Carbonyl Carbonyl Interactions in Transition-Metal Complexes. Inorg. Chem. 2018, 57, 5429-5437. [CrossRef]

37. Murcia-García, C.; Bauzá, A.; Schnakenburg, G.; Frontera, A.; Streubel, R. Surprising behaviour of M-CO(lone pair) $\cdots \pi$ (arene) interactions in the solid state of fluorinated oxaphosphirane complexes. CrystEngComm 2015, 17, 1769-1772. [CrossRef]

38. Mark-Lee, W.F.; Chong, Y.Y.; Kassim, M.B. Supramolecular structures of rhenium (I) complexes mediated by ligand planarity via the interplay of substituents. Acta Crystallogr. Sect. C Struct. Chem. 2018, 74, 997-1006.

39. Kia, R.; Hosseini, M.; Abdolrahimi, A.; Mahmoudi, M. Intermolecular C $-\mathrm{H} \cdots \mathrm{O}$ and $\mathrm{n} \rightarrow \pi^{*}$ and short intramolecular $\sigma \rightarrow \pi^{*}$ interactions in the molybdenum(0) tetracarbonyl complex of a very twisted 14-membered tetraazaannulene macrocyclic ligand: Structural and computational studies. CrystEngComm 2019, 21, 5222-5226. [CrossRef]

40. Kia, R.; Mahmoudi, S.; Raithby, P.R. New rhenium-tricarbonyl complexes bearing halogen-substituted bidentate ligands: Structural, computational and Hirshfeld surfaces studies. CrystEngComm 2019, 21, 77-93. [CrossRef] 
41. Villegas, J.M.; Stoyanov, S.R.; Huang, W.; Rillema, D.P. A spectroscopic and computational study on the effects of methyl and phenyl substituted phenanthroline ligands on the electronic structure of $\operatorname{Re}(\mathrm{I})$ tricarbonyl complexes containing 2,6-dimethylphenylisocyanide. Dalton Trans. 2005, 34, 1042-1051. [CrossRef] [PubMed]

42. Kliegman, J.M.; Barnes, R.K. Glyoxal derivatives-I: Conjugated aliphatic diimines from glyoxal and aliphatic primary amines. Tetrahedron 1970, 26, 2555-2560. [CrossRef]

43. Clark, R.C.; Reid, J.S. The analytical calculation of absorption in multifaceted crystals. Acta Cryst. 1995, A51, 887-897. [CrossRef]

44. Dolomanov, O.V.; Bourhis, L.J.; Gildea, R.J.; Howard, J.A.K.; Puschmann, H. OLEX2: A complete structure solution, refinement and analysis program. J. Appl. Cryst. 2009, 42, 339-341. [CrossRef]

45. Sheldrick, G.M. A short history of SHELX. Acta Cryst. 2008, A64, 112-122. [CrossRef]

46. Spek, A.L. Structure validation in chemical crystallography. Acta Cryst. 2009, D65, 148-155. [CrossRef]

47. Frisch, M.J.; Trucks, G.W.; Schlegel, H.B.; Scuseria, G.E.; Robb, M.A.; Cheeseman, J.R.; Scalmani, G.; Barone, V.; Mennucci, B. Gaussian 09, Revision A.02; ScienceOpen: Berlin, Germany, 2014.

48. Perdew, J.P.; Burke, K.; Ernzerhof, M. Generalized Gradient Approximation Made Simple. Phys. Rev. Lett. 1996, 77, 3865. [CrossRef]

49. Andrae, D.; Häußermann, U.; Dolg, M.; Stoll, H.; Preuß, H. Energy-adjustedab initio pseudopotentials for the second and third row transition elements. Theor. Chim. Acta 1990, 77, 123-141. [CrossRef]

50. Cotton, F.A.; Karihanzel, C.S. Vibrational Spectra and Bonding in Metal Carbonyls. I. Infrared Spectra of Phosphine-substituted Group VI Carbonyls in the CO Stretching Region. J. Am. Chem. Soc. 1962, 84, 4432-4438. [CrossRef]

51. Klein, A.; Vogler, C.; Kaim, W. The $\delta$ in $18+\delta$ Electron Complexes: Importance of the Metal/Ligand Interface for the Substitutional Reactivity of " $\operatorname{Re}(0)$ " Complexes ( $\alpha$-diimine $) \operatorname{Re}^{\mathrm{I}}(\mathrm{CO})_{3}(\mathrm{X})$. Organometallics 1996, 15, 236-244. [CrossRef]

52. Staal, L.H.; Oskam, A.; Vrieze, K. The syntheses and coordination properties of $M(C O){ }_{3} X(D A B)(M=M n, R e$; $\mathrm{X}=\mathrm{Cl}, \mathrm{Br}$, I.; DAB = 1,4-diazabutadiene). J. Organomet. Chem. 1979, 170, 235-245. [CrossRef]

53. Vollmer, M.V.; Machan, C.W.; Clark, M.L.; Antholine, W.E.; Agarwal, J.; Schaefer III, H.F.; Kubiak, C.P.; Walensky, J.R. Synthesis, Spectroscopy, and Electrochemistry of ( $\alpha$-Diimine $) \mathrm{M}(\mathrm{CO})_{3} \mathrm{Br}, \mathrm{M}=\mathrm{Mn}, \mathrm{Re}$, Complexes: Ligands Isoelectronic to Bipyridyl Show Differences in $\mathrm{CO}_{2}$ Reduction. Organometallics 2015, 34, 3-12. [CrossRef] [PubMed]

54. Abramov, P.A.; Dmitriev, A.A.; Kholin, K.V.; Gritsan, N.P.; Kadirov, M.K.; Gushchin, A.L.; Sokolov, M.N. Mechanistic study of the $\left[(\mathrm{dpp}-\mathrm{bian}) \operatorname{Re}(\mathrm{CO})_{3} \mathrm{Br}\right]$ electrochemical reduction using in situ EPR spectroscopy and computational chemistry. Electrochim. Acta 2018, 270, 526-534. [CrossRef]

55. Johnson, E.R.; Keinan, S.; Mori-Sánchez, P.; Contreras-Garcia, J.; Cohen, A.J.; Yang, W. Revealing Noncovalent Interactions. J. Am. Chem. Soc. 2010, 132, 6498-6506. [CrossRef]

56. Contreras-García, J.; Johnson, E.R.; Keinan, S.; Chaudret, R.; Piquemal, J.-P.; Beratan, D.N.; Yang, W. NCIPLOT: A program for plotting non-covalent interaction regions. J. Chem. Theory Comput. 2010, 7, 625-632. [CrossRef]

57. Usoltsev, A.N.; Adonin, S.A.; Novikov, A.S.; Samsonenko, D.G.; Sokolova, M.N.; Fedin, V.P. One-dimensional polymeric polybromotellurates (IV): Structural and theoretical insights into halogen ‥halogen contacts. CrystEngComm 2017, 19, 5934-5939. [CrossRef]

58. Glendening, E.D.; Landis, C.R.; Weinhold, F. Natural bond orbital methods. WIREs Comput. Mol. Sci. 2012, 2, 1-42. [CrossRef]

(C) 2020 by the authors. Licensee MDPI, Basel, Switzerland. This article is an open access article distributed under the terms and conditions of the Creative Commons Attribution (CC BY) license (http://creativecommons.org/licenses/by/4.0/). 